\title{
Effects of lighting regimen on metabolic rate in broilers
}

\author{
M. J. W. HEETKAMP ${ }^{1}$, A. M. HENKEN ${ }^{1}$, W. VAN DER HEL ${ }^{1}$ \& C. W. SCHEELE ${ }^{2}$ \\ ${ }^{1}$ Department of Animal Husbandry, Wageningen Agricultural University, P.O. Box 338, \\ NL $6700 \mathrm{AH}$ Wageningen, Netherlands \\ ${ }^{2}$ DLO-Centre for Poultry Research and Information Services 'Het Spelderholt', Spelder- \\ holt 9, NL 7361 DA Beekbergen, Netherlands
}

Received 16 August 1991; accepted 9 January 1992

\begin{abstract}
Broilers were exposed to varying periods of light $(\mathrm{L})$ and dark $(\mathrm{D})$ within 4 -h periods $(0.5 \mathrm{~L}$ to $1.5 \mathrm{~L}$ and $3.5 \mathrm{D}$ to $2.5 \mathrm{D}$ ). Effects of lighting regimen (LR) and trough position (open (F2) versus closed (F1)) during D-periods on heat production $(\mathrm{H})$, activity-free $\left(\mathrm{H}_{\mathrm{acf}}\right)$ and activity-related $\mathrm{H}\left(\mathrm{H}_{\mathrm{ac}}\right)$, and $\mathrm{RQ}$ were evaluated. At $0.5 \mathrm{~L}$ and $0.67 \mathrm{~L}, \mathrm{H}_{\mathrm{ac}}$ was less than in the longer L-periods. The longer the L-period, the less active animals were at the end of a L-period. In D-periods with $\mathrm{F} 1, \mathrm{H}$ and $\mathrm{H}_{\text {acf }}$ decreased more than with $\mathrm{F} 2$, while $\mathrm{H}_{\mathrm{ac}}$ was similar. Therefore, after D-periods with $\mathrm{F} 1, \mathrm{H}$ and $\mathrm{H}_{\text {acf }}$ increased more than after D-periods with $\mathrm{F} 2$. This effect on $\mathrm{H}$ was greatest in short L-periods with F1. With 0.5L:3.5D and F1, animals did not have enough feeding time, because at the end of the L-period afterwards, $\mathrm{H}$ and RQ were lower than with the longer L-periods. Thus, broilers will consume feed in the dark and the length of L-period may not be crucial, because in practice, feed will remain available in the dark.
\end{abstract}

Keywords : broilers, lighting regimen, metabolic rate, physical activity, respiratory quotient

\section{Introduction}

Many investigators have studied the effects of lighting regimen (LR) on growth rate, feed intake and mortality of broilers (Buckland, 1975; Perry, 1981; Ketelaars et al., 1986; Scheele et al., 1987); however, the effects of LR on metabolic rate, respiratory quotient ( $\mathrm{RQ}$, volume of $\mathrm{CO}_{2}$ produced divided by volume of $\mathrm{O}_{2}$ consumed) and physical activity have not been well studied. Wenk \& van Es (1976) and Scheele et al. (1987; literature review) showed that LR affects the physical activity of chickens. Scheele et al. (1987) concluded that physical activity is the most important component for losses of dietary energy. The RQ can be looked upon as a reflection of which kind of substrate is being oxidized (Brouwer, 1957); the RQ is lowered when there is no more energy available for direct assimilation. The length of the D-period could be established by knowing the moment that the RQ starts to decrease. As the average transit time of feed in 
young chickens is less than $3 \mathrm{~h}$ (Golian \& Polin, 1984), one would expect a decrease of RQ after about $3 \mathrm{~h}$ of darkness. However, van Kampen (1989) found that the change in RQ between $\mathrm{L}$ - and D-periods (1L:3D) is very limited. Firstly, as van Kampen (1989) suggested, the occurrence of feed intake in the dark should be established. Furthermore, as Scheele (1988) suggested, the feed should contain no added fat in order to maximize a possible decrease in RQ during periods with no feed intake. Several authors (Buckland, 1975; Ketelaars et al., 1986) suggest that a LR with 0.5 to $1 \mathrm{~h}$ light (L) and 2 to $3 \mathrm{~h}$ dark (D), such as $1 \mathrm{~L}: 3 \mathrm{D}$, is most suitable for broilers. The physiological basis for such a statement is unknown, but should involve a pattern of metabolic rate, RQ and/or physical activity during Land D-periods. A hypothesis might be that in D-periods, without feed intake, metabolic rate and RQ will decrease. When a minimum level is reached, light should be provided to allow feed intake. The objective of the present experiment was, therefore, to investigate the occurrence and also the magnitude of a possible decrease in heat production and RQ during D-periods of several lengths. To determine if the birds consumed feed in the dark, the feed trough was closed during some D-periods. In addition, physical activity was measured to determine its contribution to metabolic rate in relation to LR.

\section{Materials and methods}

\section{Animals, housing and feeding}

Eighty neonatal male broilers were used, 40 from each of two selection lines (S1, selected on high growth rate; S2, selected on low feed:gain ratio; Leenstra, 1987). The S1 and S2 chickens were group housed in one of two identical climate respiration chambers with one selection line per chamber. Each chamber had a volume of $1.8 \mathrm{~m}^{3}$ and a floor space of $0.8 \mathrm{~m}^{2}$ (Verstegen et al., 1987). The experiment lasted for $43 \mathrm{~d}$. Each week, a certain number of randomly selected birds was removed to maintain sufficient feeding and floor space for the remaining birds. At d 43, $6 \mathrm{~S} 1$ and $8 \mathrm{~S} 2$ birds remained. From $\mathrm{d} 1$ to $\mathrm{d} 5$, ambient temperature $\left(\mathrm{T}_{\mathrm{a}}\right)$ was maintained at $32{ }^{\circ} \mathrm{C}$. From d 6 to d $29, \mathrm{~T}_{\mathrm{a}}$ was decreased stepwise by $1{ }^{\circ} \mathrm{C}$ every 2 or $3 \mathrm{~d}$. From d 29 to d $43, \mathrm{~T}_{\mathrm{a}}$ was maintained at $20^{\circ} \mathrm{C}$. Relative humidity was maintained at 65 to $70 \%$ throughout the experiment. Feed and water were available ad libitum. Feed composition is shown in Table 1.

\section{Lighting regimens}

After $5 \mathrm{~d}$ of adaptation with continuous lighting, the animals were exposed to different LR's (Figure 1). Each day (0900 - 0900) was divided into six successive 4-h periods. Lighting was provided for 0.5 to $1.5 \mathrm{~h}$ at the start of each period (79 to 83 lux at animal level from 2 light bulbs of $25 \mathrm{~W}$ per chamber). For the remaining 2.5 to $3.5 \mathrm{~h}$, lights were off. After 2 or $3 \mathrm{~d}$ (Figure 1), LR within each 4-h period was changed. After changing LR, a new 1 or 2 day acclimatization period started. The $1 \mathrm{~L}: 3 \mathrm{D}$ regimen was repeated every $7 \mathrm{~d}$. The procedure from 
d 1 to 21 was identical to that from d 22 to 42 .

\section{Measurements}

On the last $\mathrm{d}$ of each $\mathrm{LR}$, heat production $(\mathrm{H})$ and $\mathrm{RQ}$ were determined at successive 9-min intervals for $24 \mathrm{~h}$ (respiration days, R, Figure 1) using the exchange of oxygen and carbon dioxide as described by Verstegen et al. (1987), according to the formula of Romijn \& Lokhorst (1961). Physical activity of the animals was measured during each $\mathrm{R}$ at 3-min intervals with an ultrasonic burglar device according to the method used by Wenk \& van Es (1976). These 3-min activity measurements were combined into 9 -min periods. The broilers were

Table 1. Composition and calculated feeding value of the experimental diet.

\begin{tabular}{|c|c|}
\hline Feed components & Composition (\% of feed) \\
\hline Corn & 54.0 \\
\hline Corn glutenfeed USA $(23 \% \mathrm{CP})$ & 7.8 \\
\hline Soybean solvent extracted ( $49 \% \mathrm{CP}$ ) & 23.9 \\
\hline Herring meal, Danish ( $73 \% \mathrm{CP})$ & 2.0 \\
\hline Meat meal, high fat ( $58 \% \mathrm{CP})$ & 4.0 \\
\hline Soya oil & 5.2 \\
\hline Dicalcium phosphate & 0.45 \\
\hline Vitamins $^{1}$ & 0.5 \\
\hline Minerals $^{2}$ & 2.0 \\
\hline DL-Methionine ( $99 \%$ ) & 0.1 \\
\hline Amprolium $^{3}$ & 0.05 \\
\hline Total & 100.0 \\
\hline $\mathrm{ME}_{\mathrm{n}}, \mathrm{MJ}^{4} \cdot \mathrm{kg}^{-1}$ feed & 13.18 \\
\hline Dry matter, \% & 91.08 \\
\hline Crude protein, \% & 22.1 \\
\hline Crude fibre, \% & 2.5 \\
\hline Lys (digestible), \% & 0.99 \\
\hline Met + Cys (digestible), \% & 0.71 \\
\hline Calcium, \% & 1.18 \\
\hline Magnesium, \% & 0.18 \\
\hline Phosphorus (available), \% & 0.52 \\
\hline Potassium, \% & 0.84 \\
\hline Sodium, \% & 0.18 \\
\hline
\end{tabular}

\footnotetext{
${ }^{1}$ The vitamin premix supplied per kilogram of ration: vitamin $A, 12000 \mathrm{IU}$; vitamin $\mathrm{B}_{1}, 1 \mathrm{mg}$; vitamin $B_{2}, 5 \mathrm{mg}$; nicotinic acid, $30 \mathrm{mg}$; pantothenic acid, $7.5 \mathrm{mg}$; vitamin $\mathbf{B}_{6}, 1 \mathrm{mg}$; vitamin $\mathrm{B}_{12}$, $15 \mu \mathrm{g}$; folic acid, $1 \mathrm{mg}$; vitamin $\mathrm{D}_{3}, 2400 \mathrm{IU}$; vitamin $\mathrm{E}, 15 \mathrm{mg}$; vitamin $\mathrm{K}_{3}, 1.5 \mathrm{mg}$; choline chloride, $350 \mathrm{mg}$ and ethoxyquin, $50 \mathrm{mg}$.

${ }^{2}$ The mineral premix supplied per kilogram of ration: dicalcium phosphate, $8 \mathrm{~g}, \mathrm{CaCO}_{3}, 8.8 \mathrm{~g}$; $\mathrm{NaCl}, 2.5 \mathrm{~g} ; \mathrm{CuSO}_{4} \cdot 5 \mathrm{H}_{2} \mathrm{O}, 0.04 \mathrm{~g} ; \mathrm{ZnSO}_{4}, 0.06 \mathrm{~g} ; \mathrm{MnSO}_{4}, 0.24 \mathrm{~g} ; \mathrm{FeSO}_{4}, 0.26 \mathrm{~g} ; \mathrm{I}, 0.77 \mathrm{mg} ; \mathrm{K}$, $0.23 \mathrm{mg}$ and $\mathrm{Se}, 0.1 \mathrm{mg}$.

${ }^{3}$ Merck, Sharp and Dohme (MSD), Haarlem, the Netherlands.

${ }^{4} 1 \mathrm{MJ}=0.239$ Mcal.
} 


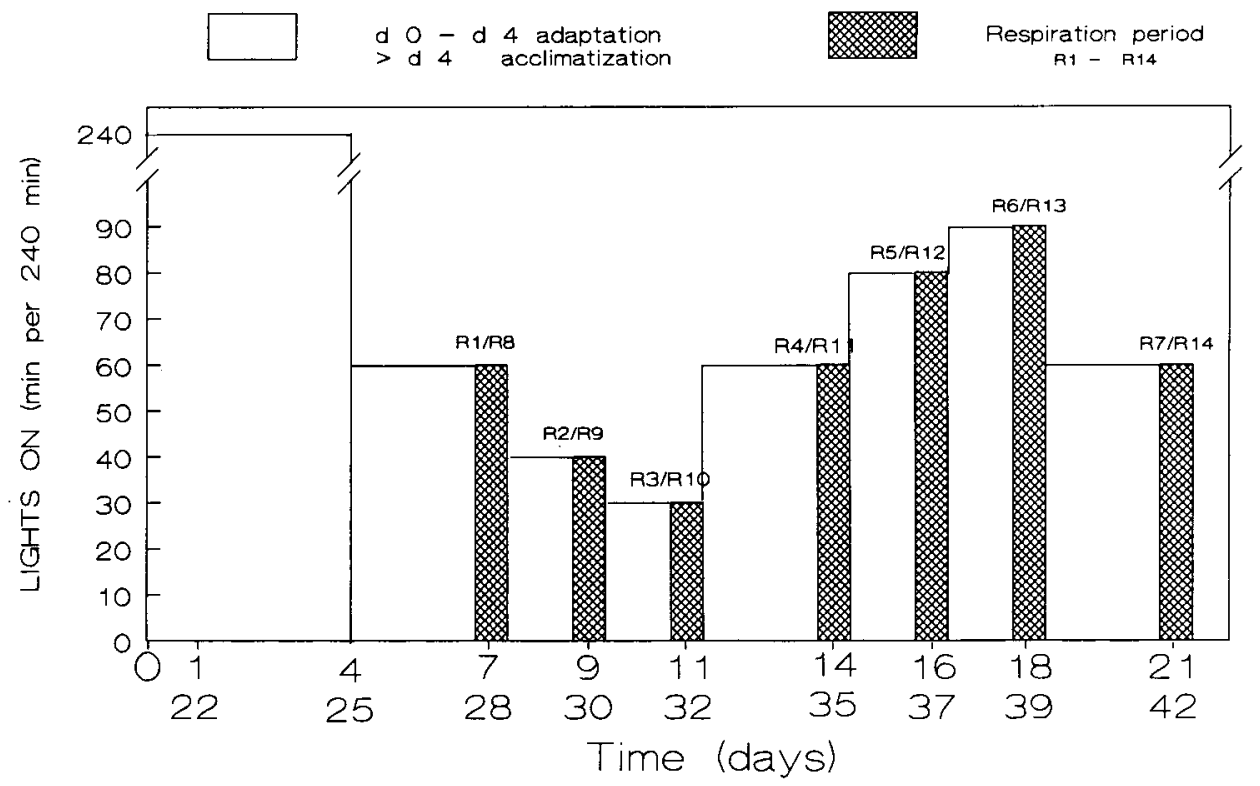

Fig. 1. Experimental design.

group-weighed after each respiration period. Also, individual body weight was determined each week, starting at $\mathrm{d} 1$. Total feed intake per group over $43 \mathrm{~d}$ was determined by summation of intake as measured during 6 successive 7 -d periods. To investigate whether feed intake occurred in the dark, the feed trough was closed during D-periods of the first two 4-h periods of each respiration day, except during d 14 (R4) and d 37 (R12) (Figure 1).

\section{Statistical analysis}

Individual body weights and growth rates (from animals still present at d 43) were analyzed for the effects of selection line (S) in a monofactorial model. Data on body weight and feed intake over $43 \mathrm{~d}$ were used to determine the effect of selection line on feed:gain ratio. From the data on $\mathrm{H}\left(\mathrm{kJ} \cdot \mathrm{kg}^{-1} \cdot \mathrm{d}^{-1}\right)$ and activity, activity-related heat production $\left(\mathrm{H}_{\mathrm{ac}}\right)$ was derived. In short, heat production was regressed on activity counts within each respiration day. Subsequently, $\mathrm{H}_{\mathrm{ac}}$ was calculated by multiplying the regression coefficient by the total number of activity counts; then, activity-free heat production $\left(\mathrm{H}_{\mathrm{acf}}\right)$ was calculated by subtracting $\mathrm{H}_{\mathrm{ac}}$ from $\mathrm{H}$. The relationship between the output of an activity meter and $\mathrm{H}$ within a day was considered linear because the correlation coefficients were 0.6 to 0.9 (Wenk \& van Es, 1976; Verstegen et al., 1987). The 24-h means of $\mathrm{H}, \mathrm{H}_{\mathrm{ac}}, \mathrm{H}_{\mathrm{acf}}$ and RQ were analyzed in a model with selection line (S) and lighting regimen (LR) as factors. Only main factors were used because the interactions between $\mathrm{S}$ and LR were not significant $(P>0.05)$. 
Differences in $\mathrm{H}, \mathrm{H}_{\mathrm{acf}}, \mathrm{H}_{\mathrm{ac}}$ and $\mathrm{RQ}$ between the last $20 \mathrm{~min}$ in L- and D-periods within each 4 -h period were analyzed with the model:

$$
Y_{i j k}=\mu+S_{i}+L R_{j}+F_{k}+e_{i j k}
$$

with: $Y=$ difference in $\mathrm{H}, \mathrm{H}_{\mathrm{acf}}, \mathrm{H}_{\mathrm{ac}}$ or $\mathrm{RQ}$ between $\mathrm{L}$ and $\mathrm{D} ; \mu=$ mean of the difference; $S_{i}=$ effect of selection line $(i=1,2) ; L R_{j}=$ effect of lighting regimen $(j=1,5) ; F_{k}=$ effect of feed trough $(\mathrm{k}=1,2$; closed or open $) ; e_{i j k}=$ error term.

A 20 -min time length was used because the shortest L-period was $30 \mathrm{~min}$ (0.5L:3.5D); thus, all periods contained two 9-min measurements. A model with only main factors was used, because the two- and three-way interactions were not significant $(P>0.05)$, except for the interaction between $\mathrm{S}$ and $\mathrm{F}$ for $\mathrm{H}_{\text {acf }}(P<$ 0.05). After a preliminary analysis, data from R1 were omitted, because the variation between 9-min data were large compared with that during other respiration days, probably due to still insufficient adaptation. Data from 11 respiration days were used for analyses of 24-h averages ( $R$ 2, 3, 5 to 11, 13, 14, Figure 1). Data from 13 respiration days were used for analyses of variation within days ( $R$ 2 to 14 , Figure 1).

\section{Results}

Body weight, growth rate, feed intake and feed:gain ratio

Chickens from the line selected for high growth rate (S1) had higher daily gain than those from the line selected for low feed:gain ratio (S2) $(P<0.001)$ (Table 2). At $43 \mathrm{~d}$ of age, the difference in body weight between chickens of S1 and S2 lines was about $430 \mathrm{~g}$. Chickens from the S1 line, although not statistically tested because of time-effect, had higher feed intake, higher daily gain and lower feed:gain ratio than those from the S2 line (Table 2).

Heat production $(H)$, activity-free heat production $\left(H_{\text {acf }}\right)$, activity-related heat production $\left(H_{a c}\right)$ and respiratory quotient $(R Q)$

Daily averages. Average daily $\mathrm{H}, \mathrm{H}_{\mathrm{acf}}$ and $\mathrm{RQ}$ were not affected $(P>0.05)$ by selection line or lighting regimen (Table 3). Activity-related heat production, $\mathrm{H}_{\mathrm{ac}}$, differed $(P<0.01)$ between lines and also between lighting regimen. From d 14 onwards, S2 line chickens spent more energy on activity than the S1 line chickens (Figure 2). At $0.5 \mathrm{~L}$ and $0.67 \mathrm{~L}$, less energy was spent on activity in comparison to longer L-periods (Table 3).

Variation within days. The differences in $\mathrm{H}, \mathrm{H}_{\mathrm{acf}}, \mathrm{H}_{\mathrm{ac}}(P<0.01)$ and $\mathrm{RQ}(P<$ $0.05)$ between $\mathrm{L}$ - and D-periods differed between selection lines (Table 4). Heat production $(\mathrm{H})$ and $\mathrm{H}_{\mathrm{ac}}$ (Figure 3 ) as well as $\mathrm{H}_{\text {acf }}$ and $\mathrm{RQ}$ were higher during the last $20 \mathrm{~min}$ in L-periods than during the last $20 \mathrm{~min}$ in D-periods. At the end of D-periods, $\mathrm{H}, \mathrm{H}_{\mathrm{acf}}, \mathrm{H}_{\mathrm{ac}}$ and $\mathrm{RQ}$ were similar in the two selection lines (mean 


\section{J. W. HEETKAMP, A. M. HENKEN, W. VAN DER HEL AND C. W. SCHEELE}

Table 2. Body weight $\left(g \cdot a n^{-1}\right)$, growth rate $\left(g \cdot a n^{-1} \cdot d^{-1}\right.$, feed intake $\left(g \cdot a n^{-1} \cdot d^{-1}\right)$ and feed:gain ratio of chickens from the two selection lines ( $\mathrm{S} 1$, selected on high growth rate; $\mathrm{S} 2$, selected on low feed:gain ratio) during the $43 \mathrm{~d}$ experiment (Means $\pm \mathrm{SE}$; number of animals between brackets).

Parameter

body weight at

d 8
d 15
d 22
d 29
d 36
d 43

growth rate of remaining animals

feed intake ${ }^{2}$

average gain

feed:gain ratio

Selection line

S1 S2

\begin{tabular}{|c|c|c|c|c|c|}
\hline 1 & $47 \pm 1$ & $(40)$ & $* * * 1$ & $42 \pm 1$ & $(40)$ \\
\hline 8 & $159 \pm 2$ & (40) & $* * *$ & $124 \pm 2$ & (39) \\
\hline 15 & $380 \pm 5$ & (33) & $* * *$ & $275 \pm 6$ & (35) \\
\hline 22 & $741 \pm 22$ & (15) & $* * *$ & $516 \pm 13$ & $(20)$ \\
\hline 29 & $1206 \pm 49$ & (11) & $* * *$ & $853 \pm 54$ & (13) \\
\hline 36 & $1798 \pm 48$ & (6) & $* * *$ & $1417 \pm 36$ & (9) \\
\hline 43 & $2374 \pm 62$ & ( 6$)$ & $* * *$ & $1947 \pm 51$ & ( 8 ) \\
\hline $\mathrm{d} 43$ & $55 \pm 1.5$ & ( 6$)$ & $* * *$ & $45 \pm 1.2$ & $(8)$ \\
\hline & $92 \pm 23$ & (6) & $\mathrm{nt}^{3}$ & $81 \pm 22$ & (6) \\
\hline & $55 \pm 11$ & ( 6$)$ & nt & $45 \pm 12$ & (6) \\
\hline & $1.58 \pm 0.1$ & ( 6$)$ & nt & $1.67 \pm 0.1$ & (6) \\
\hline
\end{tabular}

${ }^{1}$ Significant difference between selection lines $(P<0.001)$.

${ }^{2}$ Using data from 6 successive 7 -d periods.

${ }^{3} \mathrm{nt}$ - not statistically tested.

Table 3. Least square means $( \pm \mathrm{SE})$ of $24 \mathrm{~h}$ heat production $(\mathrm{H})$, activity-free heat production $\left(\mathrm{H}_{\mathrm{acf}}\right)$, activity-related heat production $\left(\mathrm{H}_{\mathrm{ac}}\right)$ and Respiratory Quotient (RQ) using a model with selection lines ( $\mathrm{S} 1$, selected on high growth rate; $\mathrm{S} 2$, selected on low feed:gain ratio) and lighting regimens (LR, 0.5 to $1.5 \mathrm{~h}$ of light in each 4 -h period) as main factors.

\begin{tabular}{|c|c|c|c|c|c|}
\hline \multicolumn{2}{|c|}{ Source of variation } & \multirow{2}{*}{$\begin{array}{l}\mathrm{H} \\
\left(\mathrm{kJ} \cdot \mathrm{kg}^{-1} \cdot \mathrm{d}^{-1}\right) \\
830 \pm 19 \\
867 \pm 19\end{array}$} & \multirow{2}{*}{$\begin{array}{l}\mathrm{H}_{\mathrm{acf}} \\
\left(\mathrm{kJ} \cdot \mathrm{kg}^{-1} \cdot \mathrm{d}^{-1}\right) \\
747 \pm 17 \\
748 \pm 17\end{array}$} & \multirow{2}{*}{$\begin{array}{l}\mathrm{H}_{\mathrm{ac}} \\
\left(\mathrm{kJ} \cdot \mathrm{kg}^{-1} \cdot \mathrm{d}^{-1}\right) \\
83 \pm 5^{\mathrm{B}} \\
119 \pm 5^{\mathrm{A}}\end{array}$} & \multirow{2}{*}{$\begin{array}{l}\mathrm{RQ} \\
\left(\mathrm{CO}_{2} / \mathrm{O}_{2}\right) \\
1.07 \pm 0.01 \\
1.05 \pm 0.01\end{array}$} \\
\hline Line: & $\begin{array}{l}\text { S1 } \\
\text { S2 }\end{array}$ & & & & \\
\hline LR: & $\begin{array}{c}0.5 \mathrm{~L}: 3.5 \mathrm{D} \\
0.67 \mathrm{~L}: 3.33 \mathrm{D} \\
1 \mathrm{~L}: 3 \mathrm{D} \\
1.33 \mathrm{~L}: 2.67 \mathrm{D} \\
1.5 \mathrm{~L}: 2.5 \mathrm{D}\end{array}$ & $\begin{array}{l}855 \pm 30 \\
816 \pm 30 \\
870 \pm 21 \\
839 \pm 42 \\
863 \pm 30\end{array}$ & $\begin{array}{l}780 \pm 27 \\
733 \pm 27 \\
761 \pm 19 \\
720 \pm 38 \\
744 \pm 27\end{array}$ & $\begin{array}{c}75 \pm 7^{\mathrm{B}} \\
83 \pm 7^{\mathrm{B}} \\
109 \pm 5^{\mathrm{A}} \\
119 \pm 10^{\mathrm{A}} \\
119 \pm 7^{\mathrm{A}}\end{array}$ & $\begin{array}{l}1.05 \pm 0.02 \\
1.07 \pm 0.02 \\
1.04 \pm 0.01 \\
1.10 \pm 0.02 \\
1.06 \pm 0.02\end{array}$ \\
\hline $\begin{array}{l}\text { MS model } \\
\text { MS error } \\
R^{2}\end{array}$ & $\begin{array}{l}(\mathrm{df}=5) \\
(\mathrm{df}=16)\end{array}$ & $\begin{array}{l}3085 \\
3530 \\
0.21\end{array}$ & $\begin{array}{l}1516 \\
2866 \\
0.14\end{array}$ & $\begin{array}{l}2683 \\
211 \\
0.80\end{array}$ & $\begin{array}{l}0.0015 \\
0.0010 \\
0.33\end{array}$ \\
\hline
\end{tabular}

A.B: values of classes within the same factor with different superscripts differ significantly $(P<$ $0.01)$.

SE: standard error; MS: Mean Squares; df: degrees of freedom; $R^{2}$ : coefficient of determination. 
$-H_{\mathrm{ac}} \mathrm{S1} \quad \ldots-\cdots \mathrm{H}_{\mathrm{ac}} \mathrm{S} 2$

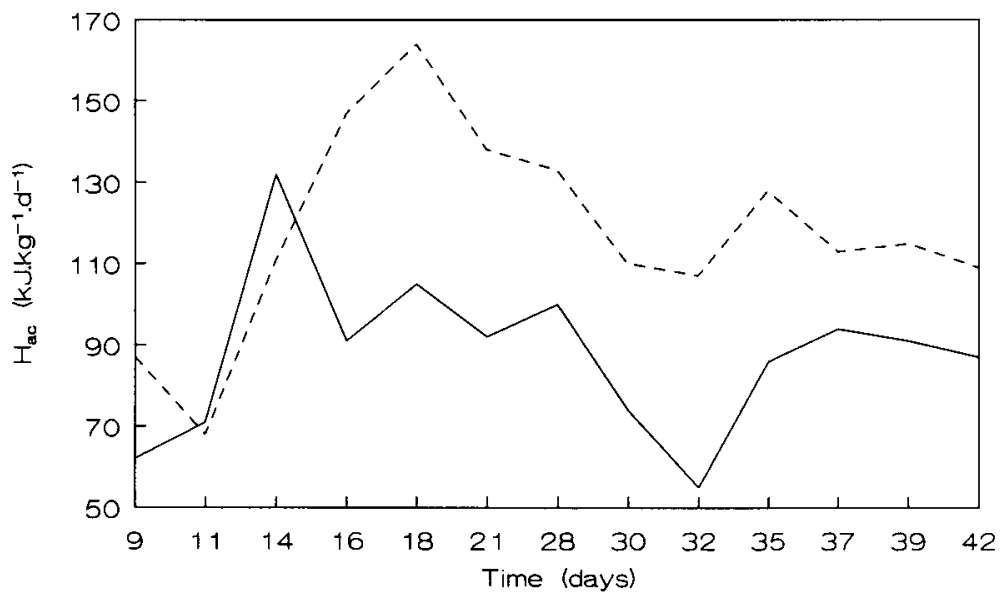

Fig. 2. Activity-related heat production $\left(\mathrm{H}_{\mathrm{ac}}\right)$ of chickens selected on high growth rate $(\mathrm{S} 1)$ and on low feed:gain ratio $(\mathrm{S} 2)$ in relation to duration of the experiment.

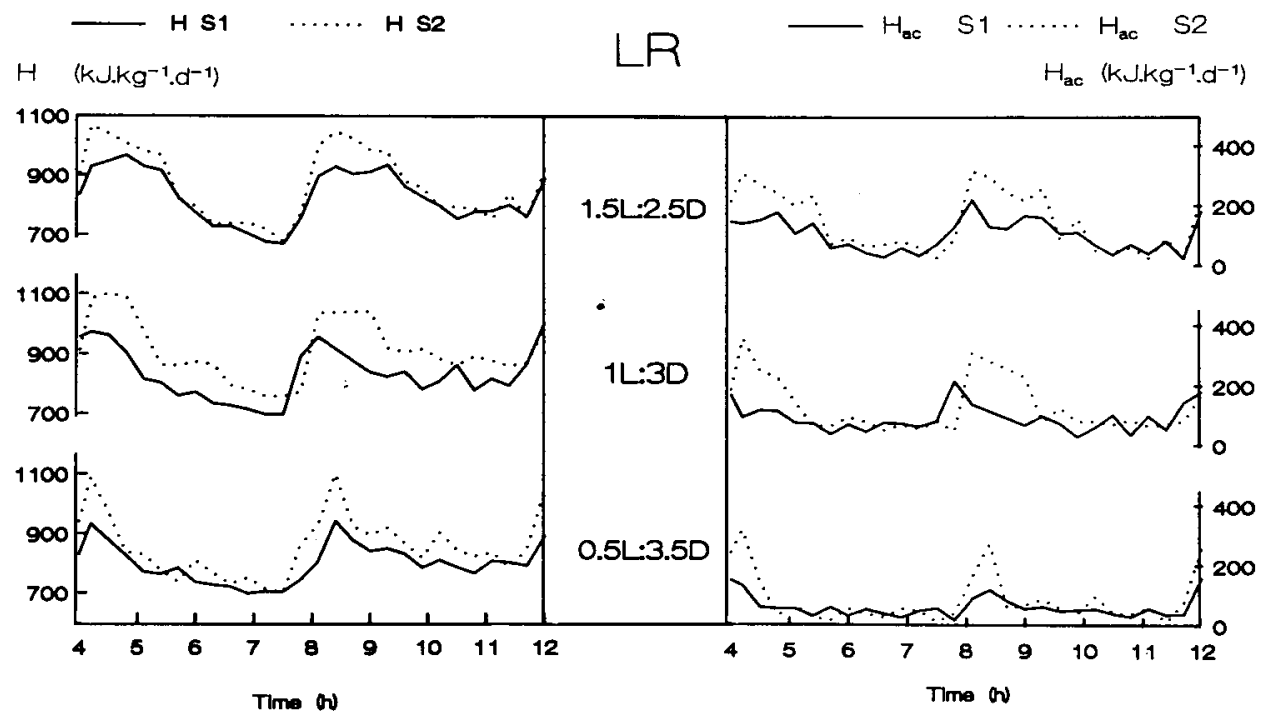

Fig. 3. Total heat production $(\mathrm{H})$ and activity-related heat production $\left(\mathrm{H}_{\mathrm{ac}}\right)$ within selection lines $(\mathrm{S} 1$, selected on growth rate; $\mathrm{S} 2$, selected on feed:gain ratio) and lighting regimens (LR, 0.5 to $1.5 \mathrm{~h}$ of light in each 4-h period) of 18-min averages (two 9-min intervals). 
Table 4. Least square means ( $\pm \mathrm{SE}$ ) of differences between the last $20 \mathrm{~min}$ in the light and the last $20 \mathrm{~min}$ in the dark within a 4-h period of heat production $(\mathrm{H})$, activity-free heat production $\left(\mathrm{H}_{\mathrm{ac}}\right)$, activity-related heat production $\left(\mathrm{H}_{\mathrm{ac}}\right)$ and Respiratory Quotient $(\mathrm{RQ})$ using a model with selection lines (S1, selected on high growth rate; S2, selected on low feed:gain ratio), lighting regimens (LR, 0.5 to $1.5 \mathrm{~h}$ of light in each 4-h period) and feed restriction (F1, feed trough closed in the dark; F2, feeding trough open in the dark) as main factors.

\begin{tabular}{|c|c|c|c|c|c|}
\hline $\begin{array}{l}\text { Source of } \\
\text { variation }\end{array}$ & & $\begin{array}{l}\mathrm{H} \\
\left(\mathrm{kJ} \cdot \mathrm{kg}^{-1} \cdot \mathrm{d}^{-1}\right)\end{array}$ & $\begin{array}{l}\mathrm{H}_{\text {acf }} \\
\left(\mathrm{kJ} \cdot \mathrm{kg}^{-1} \cdot \mathrm{d}^{-1}\right)\end{array}$ & $\begin{array}{l}\mathrm{H}_{\mathrm{ac}} \\
\left(\mathrm{kJ} \cdot \mathrm{kg}^{-1} \cdot \mathrm{d}^{-1}\right)\end{array}$ & $\begin{array}{l}\mathrm{RQ} \\
\left(\mathrm{CO}_{2} / \mathrm{O}_{2}\right)\end{array}$ \\
\hline Line: & $\begin{array}{l}\text { S1 } \\
\text { S2 }\end{array}$ & $\begin{array}{l}201 \pm 10^{\mathrm{B}} \\
305 \pm 10^{\mathrm{A}}\end{array}$ & $\begin{array}{r}113 \pm 9^{\mathrm{A}} \\
80 \pm 9^{\mathrm{B}}\end{array}$ & $\begin{array}{r}88 \pm 9^{\mathrm{B}} \\
224 \pm 9^{\mathrm{A}}\end{array}$ & $\begin{array}{l}0.04 \pm 0.01^{\mathrm{a}} \\
0.02 \pm 0.01^{\mathrm{b}}\end{array}$ \\
\hline LR: & $\begin{array}{c}0.5 \mathrm{~L}: 3.5 \mathrm{D} \\
0.67 \mathrm{~L}: 3.33 \mathrm{D} \\
1 \mathrm{~L}: 3 \mathrm{D} \\
1.33 \mathrm{~L}: 2.67 \mathrm{D} \\
1.5 \mathrm{~L}: 2.5 \mathrm{D}\end{array}$ & $\begin{array}{l}253 \pm 16 \\
282 \pm 16 \\
255 \pm 11 \\
240 \pm 24 \\
234 \pm 16\end{array}$ & $\begin{aligned} 53 & \pm 14^{\mathrm{B}} \\
106 & \pm 14^{\mathrm{A}} \\
129 & \pm 10^{\mathrm{A}} \\
90 & \pm 22^{\mathrm{A}} \\
104 & \pm 14^{\mathrm{A}}\end{aligned}$ & $\begin{array}{l}200 \pm 14^{\mathrm{A}} \\
176 \pm 14^{\mathrm{AB}} \\
126 \pm 10^{\mathrm{C}} \\
150 \pm 22^{\mathrm{CB}} \\
129 \pm 14^{\mathrm{C}}\end{array}$ & $\begin{array}{l}0.00 \pm 0.01 \\
0.01 \pm 0.01 \\
0.04 \pm 0.01 \\
9.05 \pm 0.02 \\
0.04 \pm 0.01\end{array}$ \\
\hline feed: & $\begin{array}{l}\mathrm{F} 1 \\
\mathrm{~F} 2\end{array}$ & $\begin{array}{l}312 \pm 12^{A} \\
193 \pm 9^{B}\end{array}$ & $\begin{aligned} 151 & \pm 11^{\mathrm{A}} \\
42 & \pm 8^{\mathrm{B}}\end{aligned}$ & $\begin{array}{l}161 \pm 11 \\
151 \pm 8\end{array}$ & $\begin{array}{r}0.07 \pm 0.01^{\mathrm{A}} \\
-0.01 \pm 0.01^{\mathrm{B}}\end{array}$ \\
\hline interaction: & $\begin{array}{l}\mathrm{S} 1 \times \mathrm{F} 1 \\
\mathrm{~S} 1 \times \mathrm{F} 2 \\
\mathrm{~S} 2 \times \mathrm{F} 1 \\
\mathrm{~S} 2 \times \mathrm{F} 2\end{array}$ & n.s. & $\begin{array}{r}187 \pm 15^{\mathrm{a}} \\
48 \pm 11^{\mathrm{b}} \\
114 \pm 15^{\mathrm{c}} \\
36 \pm 11^{\mathrm{d}}\end{array}$ & n.s. & n.s. \\
\hline $\begin{array}{l}\text { MS model } \\
\text { MS error } \\
R^{2}\end{array}$ & $\begin{array}{l}(\mathrm{df}=6) \\
(\mathrm{df}=126)\end{array}$ & $\begin{array}{r}132681 \\
5817 \\
0.52\end{array}$ & $\begin{array}{r}70869 \\
4456 \\
0.47\end{array}$ & $\begin{array}{r}123298 \\
4638 \\
0.56\end{array}$ & $\begin{array}{l}0.039 \\
0.004 \\
0.34\end{array}$ \\
\hline
\end{tabular}

A.B.C. values of classes within the same factor with different superscripts differ significantly $(\mathrm{P}<0.01)$. a.b.c.d: values of classes within the same factor with different superscripts differ significantly $(\mathrm{P}<0.05)$.

SE: Standard error; MS: Mean Squares; df: degrees of freedom; $R^{2}$ : coefficient of determination; n.s.: not significant.

values: $732,683,49 \mathrm{~kJ} \cdot \mathrm{kg}^{-1} \cdot \mathrm{d}^{-1}$ and 1.02 , for the $\mathrm{S} 1$ and $\mathrm{S} 2$ lines, respectively). At the end of the L-periods, $H$ of S1 and S2 chickens was 924 and $1031 \mathrm{~kJ} \cdot \mathrm{kg}^{-1} \cdot \mathrm{d}^{-1}$, respectively, and $\mathrm{H}_{\mathrm{ac}}$ was 138 and $264 \mathrm{~kJ} \cdot \mathrm{kg}^{-1} \cdot \mathrm{d}^{-1}$, respectively; however, with respect to $\mathrm{H}_{\mathrm{acf}}$ and $\mathrm{RQ}$ the differences were in the opposite direction. Thus, the $\mathrm{H}_{\mathrm{acf}}$ and RQ of S1 chickens decreased significantly more between the L- to D-periods than those of S2 chickens.

Lighting regimen affected the difference in $\mathrm{H}_{\text {acf }}$ and in $\mathrm{H}_{\mathrm{ac}}(P<0.01)$ between the $\mathrm{L}$ - and D-periods. At $0.5 \mathrm{~L}: 3.5 \mathrm{D}$, the difference in $\mathrm{H}_{\mathrm{acf}}$ was smallest $(P<$ $0.01)$ due to high value at the end of the D-period $\left(718 \mathrm{~kJ} \cdot \mathrm{kg}^{-1} \cdot \mathrm{d}^{-1}\right)$. In the same $\mathrm{LR}$, the difference in $\mathrm{H}_{\mathrm{ac}}$ was highest due to high activity at the end of the L-period $\left(247 \mathrm{~kJ} \cdot \mathrm{kg}^{-1} \cdot \mathrm{d}^{-1}\right)$. At 1L:3D, 1.33L:2.67D and 1.5L:2.5D, the difference in $\mathrm{H}_{\mathrm{ac}}$ was lowest due to low activity at the end of the L-period (mean value: 181 $\left.\mathrm{kJ} \cdot \mathrm{kg}^{-1} \cdot \mathrm{d}^{-1}\right)$.

Feed restriction in D-periods (F1) compared with open troughs (F2) caused ( $P$ $<0.01$ ) differences in $\mathrm{H}$ and $\mathrm{H}_{\text {acf }}$ between $\mathrm{L}$ - and $\mathrm{D}$-periods due to lower values at the end of D-periods (F1: 667 and 623, F2: 797 and $742 \mathrm{~kJ} \cdot \mathrm{kg}^{-1} \cdot \mathrm{d}^{-1}$ ). In both 
$F 1$ and $F 2$, the difference between $L$ - and D-periods for $\mathrm{H}_{\text {acf }}$ was dependent on line. Feed restriction had a greater effect on this difference in $\mathrm{H}_{\text {acf }}$ for the $\mathrm{S} 1$ line. At F1, RQ decreased from L- to D-periods with 0.07 on average, from 1.05 to 0.98. At F2, an increase in RQ, from 1.06 (L) to 1.07 (D), was found.

\section{Discussion}

Results on body weight, gain and feed:gain ratio of S2 chickens were similar to those obtained in the original selection experiment (Leenstra, 1987, 1988); however, the body weights of $\mathrm{S} 1$ chickens at $\mathrm{d} 43$ were high in comparison to the data of Leenstra (1987) (2374 vs. $2193 \mathrm{~g}$ ). Also, the feed:gain ratio of the S1 chickens was lower in the present experiment than those of Leenstra $(1987,1988)$. Average gain of all the animals was similar to that of the remaining animals at the end of the experiment for both S1 and S2, which means that there was no effect of randomly taking out the animals.

Earlier experiments showed $1 \mathrm{~L}: 3 \mathrm{D}$ to be superior to $23 \mathrm{~L}: 1 \mathrm{D}$ with respect to broiler performance, which was ascribed partly to reduced activity (Ketelaars et al., 1986). In our experiment, activity-related heat production was affected by lighting regimen. In longer L-periods the chickens were more active (Table 3). However, this result was not the case within a L-period itself, because activity as measured at the end of a L-period became lower as the length of the L-period increased. Therefore, within a L-period, animals became less active after the initial increased activity when the lights were switched on; however, the birds continued to be more active than those placed in the dark after a short L-period (Figure 3).

Average daily $\mathrm{H}_{\text {acf }}$ did not differ between selection lines. Chickens from the line selected on low feed:gain ratio spent more energy on activity than the S1 chickens. Activity-related heat production of the $S 1$ chickens, as measured in the present experiment, was similar to the value of $84 \mathrm{~kJ} \cdot \mathrm{kg}^{-1} \cdot \mathrm{d}^{-1}$ reported by Wenk \& van Es (1976) for ad libitum-fed chickens. It might be that selection for low feed:gain ratio results indirectly in excessive feeding behaviour, which results then in high activity-related heat production, because feed:gain ratio will be lower at higher levels of feed intake relative to maintenance.

Activity-related $\mathrm{H}$ during $\mathrm{D}$-periods with open or with closed feed troughs were similar. It is possible that the broilers were adapted to eating in the dark (Cherry \& Barwick, 1962) and, in their attempt to find feed when the trough was closed, remained similarly active as with open trough. Cherry \& Barwick (1962) reported that birds on a restricted light regimen maintained intake similar to those illuminated continuously. Wenk \& van Es (1976) found that activity-related energy costs, in terms of metabolizable energy (ME), increased from $15-20 \%$ of maintenance at ad libitum $\left(\mathrm{ME}_{\mathrm{m}}=505 \mathrm{~kJ} \cdot \mathrm{kg}^{0.75} \cdot \mathrm{d}^{-1}\right.$ to $30 \%$ of $\mathrm{ME}_{\mathrm{m}}$ when broilers were given $75 \%$ of voluntary intake. However, these authors applied a continuous restriction, while in our experiment the birds were only restricted in their feed intake in two out of six D-periods within $24 \mathrm{~h}$. In starving birds, metabolic rate decreases rapidly after the light is turned off and increases rapidly after the 
light is switched on again (van Kampen, 1987). In the present experiment, $H$, $\mathrm{H}_{\mathrm{acf}}, \mathrm{H}_{\mathrm{ac}}$ and $\mathrm{RQ}$ remained lower in a L-period following a D-period with closed compared to open troughs (differences: $43,21,22 \mathrm{~kJ} \cdot \mathrm{kg}^{-1} \cdot \mathrm{d}^{-1}$ and 0.04 , respectively).

Also, an effect of LR existed $(P<0.01)$ on differences in $\mathrm{H}$ and $\mathrm{RQ}$ in L-periods following $\mathrm{D}$-periods with open compared to closed trough $(\mathrm{H}, 0.5 \mathrm{~L}$ versus mean of $0.67+1+1.5 \mathrm{~L}=132$ versus $40 \mathrm{~kJ} \cdot \mathrm{kg}^{-1} \cdot \mathrm{d}^{-1} ; \mathrm{RQ}, 0.12$ versus 0.03 ; LR 1.33L:2.67D omitted due to missing values). Thus, at $0.5 \mathrm{~L}: 3.5 \mathrm{D}$ with closed troughs in the dark, birds did not have enough time to feed during the following L-period, because at the end of this L-period $\mathrm{H}$ and $\mathrm{RQ}$ were much lower than without feed restriction.

In each $\mathrm{LR}, \mathrm{H}, \mathrm{H}_{\mathrm{acf}}$ and $\mathrm{RQ}$ decreased more in D-periods with closed compared to open troughs, while $\mathrm{H}_{\mathrm{ac}}$ was similar. The subsequent increase in metabolic rate during the L-periods also depended on whether the feed trough in the previous D-period was open or closed. When closed, a L-period of $30 \mathrm{~min}$ is apparently too short for feed consumption and attaining normal metabolic rate. When open, differences between L- and D-period were much smaller. Because in practice feed troughs remain open in the dark, the length of L-periods may not be as crucial as thought, at least if there is enough feeding and drinking trough length available.

\section{Acknowledgements}

The authors wish to thank mrs G.M. Puls-van der Kamp, mr H.A. Brandsma, mr J.M. van der Linden and mr P. Vos for their technical assistance for the performance of the experiment.

\section{References}

Brouwer, E., 1957. On simple formulae for calculating the heat expenditure and the quantities of carbohydrate and fat oxidized in metabolism of men and animals, from gaseous exchange (oxygen intake and carbonic acid output) and urine-N. Acta Physiology Pharmacology Neerlandica 6: 795-802.

Buckland, R. B., 1975. The effect of intermittent lighting programmes on the production of market chickens and turkeys. World's Poultry Science Journal 31: 262-270.

Cherry, P. \& M. W. Barwick, 1962. The effect of light on broiler growth, II. Light patterns. British Poultry Science 3: 41-50.

Golian, A. \& D. Polin, 1984. Passage rate of feed in very young chicks. Poultry Science 63: 1013-1019.

Kampen, M. van, 1987. Climatic conditions and energy metabolism of laying hens. In: M. W. A. Verstegen \& A. M. Henken (Eds), Energy metabolism in farm animals: effects of housing, stress and disease, p. 199-216. Kluwer Academic Publishers, Dordrecht, Netherlands.

Kampen, M. van, 1989. Energy metabolism for broiler chicks under different temperature regimens. In: Y. van der Honing \& W.H. Close (Eds), Energy metabolism in farm animals, p. 247-250. Pudoc, Wageningen, Netherlands.

Ketelaars, E. H., M. Verbrugge, W. van der Hel, J. M. van der Linden \& M. W. A. Verstegen, 1986. Effect of intermittent lighting on performance and energy metabolism of broilers. Poultry Science 65: $2208-2213$.

Leenstra, F. R., 1987. Fat deposition in a broiler sire strain. Doctoral Thesis Wageningen Agricultural University. COVP publication 462,145 pp. Beekbergen, Netherlands. 
Leenstra, F. R., 1988. Selection for leanness: Results of the Spelderholt experiment. In: Leclercq, B. \& C. C. Whitehead (Eds), Leanness in domestic birds, genetic, metabolic and hormonal aspects, p. 59-69. Butterworths, London.

Perry, G. C., 1981. Growth and food intake of broilers under various lighting regimes. British Poultry Science 22: 219-225.

Romijn, C. \& W. Lokhorst, 1961. Some aspects of energy metabolism in birds. In: Proceedings 2nd Symposium Energy Metabolism of Farm Animals, p. 49-58. EAAP Publication no. 10, Rome, Italy.

Scheele, C. W., W. van der Hel, M. W. A. Verstegen \& A. M. Henken, 1987. Climatic environment and energy metabolism in broilers. In: M. W. A. Verstegen \& A. M. Henken (Eds), Energy metabolism in farm animals: effects of housing, stress and disease, p. 217-260. Kluwer Academic Publishers, Dordrecht, Netherlands.

Scheele, C. W., 1988. The extra caloric effect of fat in poultry rations. Poultry Research Institute 'Spelderholt', edition no. 493, 20 pp. Beekbergen, Netherlands.

Verstegen, M. W. A., W. van der Hel, H. A. Brandsma, A. M. Henken \& A. M. Bransen, 1987. The Wageningen respiration unit for animal production research: a description of the equipment and its possibilities. In: M. W. A. Verstegen \& A. M. Henken (Eds), Energy metabolism in farm animals: effects of housing, stress and disease, p. 21-48. Kluwer Academic Publishers, Dordrecht, Netherlands.

Wenk, C. \& A. J. H. van Es, 1976. Energy metabolism of growing chickens as related to their physical activity. In: M. Vermorel (Ed), Energy metabolism of farm animals, p. 189-192. Institut national de la recherche agronomique, Beaumont, France. 